\title{
Komparasi Penangangan Barang Bukti Elektronik dan/atau Barang Bukti Digital sesuai SOP Pusat Laboratorium Forensik Polisi Republik Indonesia ${ }^{1}$
}

\author{
Dedy Hariyadi $i^{2}$
}

\section{Pendahuluan}

Dalam situs web Federal Bureau of Investigation[1] yang dimaksud barang bukti digital adalah nilai pembuktian dari sebuah informasi yang tersimpan atau tertransmisi dalam bentul digital. Sementara itu menurut Eoghan Casey barang bukti digital merupakan data yang tersimpan atau tertransmisi menggunakan komputer baik yang bersifat mendukung atau menyanggah teori proses pelanggaran atau mengandung unsur-unsur pelanggaran seperti niat atau alibi[2].

Undang-undang Nomor 11 tahun 2008 tentang Informasi dan Transaksi Elektronik tidak menyebutkan definisi dari barang bukti digital namun ada 2 istilah serupa, yaitu informasi elektronik dan dokumen elektronik. Informasi elektronik satu atau sekumpulan data elektronik, termasuk tetapi tidak terbatas pada tulisan, suara, gambar, peta, rancangan, foto, electronic data interchange (EDI), surat elektronik (electronic mail), telegram, teleks, telecopy atau sejenisnya, huruf, tanda, angka, kode akses, simbol, atau perforasi yang telah diolah yang memiliki arti atau dapat dipahami oleh orang yang mampu memahaminya. Dokumen elektronik adalah setiap informasi elektronik yang dibuat, diteruskan, dikirimkan, diterima, atau disimpan dalam bentuk analog, digital, elektromagnetik, optikal, atau sejenisnya, yang dapat dilihat, ditampilkan, dan/atau didengar melalui Komputer atau Sistem Elektronik, termasuk tetapi tidak

1. Tugas mata kuliah Manajemen Investigasi Tindak Kriminal dengan dosen pengampu dr. Handayani Dwi Utami, M.Sc., Sp.F

2. Mahasiswa Magister Teknik Informatika UII konsentrasi Forensika Digital 13917112 -milisdad@gmail.com. 
terbatas pada tulisan, suara, gambar, peta, rancangan, foto atau sejenisnya, huruf, tanda, angka, kode akses, simbol atau perforasi yang memiliki makna atau arti atau dapat dipahami oleh orang yang mampu memahaminya [3].

Pelanggaran atau tindakan melawan hukum terhadap informasi elektronik dan/atau dokumen elektronik telah diatur pula dalam Undang-undang Nomor 11 tahun 2008 pasal 32. Sebagai contoh tindakan menyalin dokumen elektronik tanpa izin dari pemilik aslinya dianggap telah melanggar hukum. Untuk membuktikan tindakan melawan hukum seperti contoh tersebut dilakukan uji forensik digital.

\section{Aktivitas Forensik}

Richardus Eko Indrajit[4] menulis ada 14 tahapan aktivitas forensik digital:

1. Pernyataan terjadinya kejahatan komputer

2. Pengumpulan petunjuk atau bukti awal

3. Penerbitan surat pengadilan

4. Pelaksanaan prosedur tanggapan dini

5. Pembekuan barang bukti pada lokasi kejahatan

6. Pemindahan bukti ke laboratorium forensik

7. Pembuatan salinan "2 bit stream" terhadap barang bukti

8. Pengembangan "md5 checksum" barang bukti

9. Penyiapan rantai posesi barang bukti

10. Penyimpanan barang bukti asli di tempat aman

11. Analisa barang bukti salinan

12. Pembuatan laporan forensik

13. Penyerahan hasil laporan analisa

14. Penyertaan dalam proses pengadilan

Berdasarkan Standar Operating Procedure 1 Pusat Laboratorium Forensik bidang Fisika dan Komputer Forensik Polisi Republik Indonesia tentang prosedur pemeriksaan forensik digital menjelaskan penanganan setiap barang bukti elektronik dan/atau barang bukti digital memiliki tahapan yang sedikit berbeda 
antara tipe satu dengan yang lainnya[5]. Ada 6 kategori penanganan barang bukti elektronik dan/atau barang bukti digital :

1. Harddisk, flashdisk dan memory card

2. Ponsel dan simcard

3. Forensik audio

4. Forensik video

5. Forensik gambar digital

6. Forensik jaringan

\section{Komparasi Penanganan Forensik Digital}

Standar Operating Procedure (SOP) yang disusun oleh Pusat Laboratorium Forensik Polisi RI dalam menangani barang bukti digital antara satu kategori dengan kategori lainnya memiliki kesamaan atau memiliki tahapan yang sama. Terdapat 15 SOP dalam menangani setiap barang bukti elektronik dan/atau barang bukti digital[6]:

1. SOP 1 tentang prosedur analisa forensik digital

2. SOP 2 tantang komitmen jam kerja

3. SOP 3 tentang pelaporan forensik digital

4. SOP 4 tentang menerima barang bukti elektronik dan/atau digital

5. SOP 5 tentang penyerahan kembali barang bukti elektronik dan/atau digital

6. SOP 6 tentang triage forensik (penanganan awal barang bukti komputer di TKP)

7. SOP 7 tentang akuisisi langsung

8. SOP 8 tentang akuisisi harddisk, flashdisk dan memory card

9. SOP 9 tentang analisa harddisk, flashdisk dan memory card

10. SOP 10 tentang akuisisi ponsel dan simcard 
11. SOP 11 tentang analisa ponsel dan simcard

12. SOP 12 tentang analisa forensik audio

13. SOP 13 tentang analisa forensik video

14. SOP 14 tentang analisa gambar digital

15. SOP 15 tentang analisa forensik jaringan

Tabel komparasi SOP penanganan barang bukti elektronik dan/atau barang bukti digital sesuai SOP 1 dapat dilihat pada Tabel 1.

\begin{tabular}{|c|c|c|c|c|c|c|c|c|c|c|c|c|c|c|c|}
\hline \multirow{2}{*}{$\begin{array}{c}\text { Barang Bukti Elektronik dan/atau } \\
\text { Digital }\end{array}$} & \multicolumn{15}{|c|}{ SOP } \\
\hline & 1 & 2 & 3 & 4 & 5 & 6 & 7 & 8 & 9 & 10 & 11 & 12 & 13 & 14 & 15 \\
\hline Harddisk, flashdisk dan memory card & & & $\mathrm{d}$ & $\mathrm{a}$ & e & & & $\mathrm{b}$ & $\mathrm{c}$ & & & & & & \\
\hline Ponsel dan simcard & & & $\mathrm{d}$ & $\mathrm{a}$ & e & & & & & $\mathrm{b}$ & $\mathrm{c}$ & & & & \\
\hline Forensik audio & & & d & $\mathrm{a}$ & e & & & $\mathrm{b}$ & & & & $\mathrm{c}$ & & & \\
\hline Forensik video & & & $\mathrm{d}$ & $\mathrm{a}$ & e & & & $\mathrm{b}$ & & & & & $\mathrm{c}$ & & \\
\hline Forensik gambar digital & & & $\mathrm{d}$ & $\mathrm{a}$ & e & & & $\mathrm{b}$ & & & & & & $\mathrm{c}$ & \\
\hline Forensik jaringan & & & d & $\mathrm{a}$ & e & & & $\mathrm{b}$ & & & & & & & $\mathrm{c}$ \\
\hline
\end{tabular}

Tabel 1. Komparasi Penanganan Barang Bukti

\section{Kesimpulan}

Pada Tabel 1 terlihat bahwa penanganan barang bukti elektronik dan/atau barang bukti digital terdapat persamaan dan perbedaan penerapan SOP. Persamaan penerapan SOP yaitu pada menerima barang bukti elektronik dan/atau digital, pelaporan forensik digital dan penyerahan kembali barang bukti elektronik dan/atau digital. Hampir semua penanganan menerapkan SOP akuisisi harddisk, flashdisk dan memory card kecuali penanganan barang bukti elektronik berupa ponsel dan simcard. Analisa masing-masing barang bukti elektronik dan/atau digital menyesuaikan dengan kategorinya. 


\section{Daftar Pustaka}

[1] Federal Bureau of Investigation, "Digital Evidence," 2000. [Online]. Available:

http://www.fbi.gov/about-us/lab/forensic-science-communications/fsc/april 2000/swgde.htm/. [Accessed: 25-Mar-2014].

[2] E. Casey, "Digital Evidence and Computer Crime: Forensic Science, Computers and The Internet," Jurimetrics, vol. 46, no. 3, pp. 373-378, 2006.

[3] "Undang-undang Nomor 11 Tahun 2008.” 2008.

[4] R. E. Indrajit, "Forensik Komputer."

[5] Pusat Laboratorium Forensik Polisi RI, "Prosedur Pemeriksaan Digital Forensik," Jakarta, 2013.

[6] M. N. Al-Azhar, "SOP on Digital Forensic," 2013. [Online]. Available: http://www.linkedin.com/groups/SOP-on-Digital-Forensic-4439573.S.2293 88439. [Accessed: 25-Mar-2014]. 